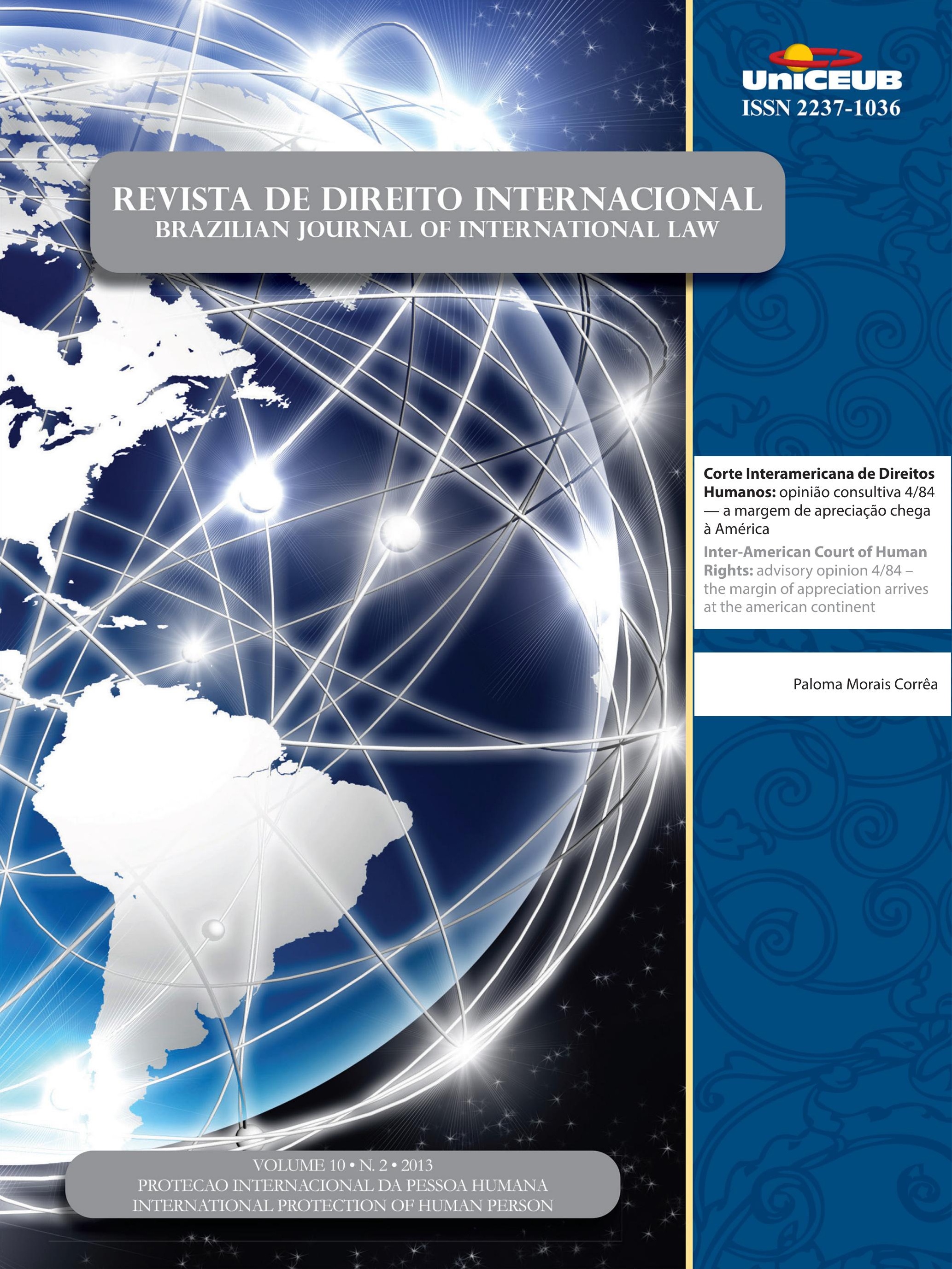




\section{Artigo Especial}

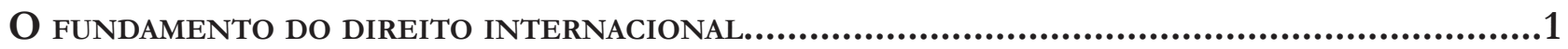
Alfred Verdross

\section{Proteção Internacional dos Direitos Humanos}

INDIGENOUS RIGHTS MOVEMENT: IS THE SAME NEEDED TO PREVENT CONTINUED HUMAN RIGHTS VIOLATIONS OF THE MENTALLY ILL

Liesel LeCates

O Discurso DAS DROGAS CONSTRUído PELO DIREITO INTERNACIONAL

Camila Soares Lippi

O ESTADO DEMOCRÁTICO DE DIREITO LAICO E A "NEUTRALIDADE" ANTE A INTOLERÂNCIA RELIGIOSA

Antonio Baptista Gonçalves

UM DiREITO SEM ESTADO? DiREITOS humanos E A FORMAÇÃo DE UM NOVO QUADRo NORMATIVO GLOBAL .87

Anderson Vichinkeski Teixeira e Rafael Köche

\section{Direito Humanitário}

The U.N. Standard Minimum Rules for the Treatment of Prisoners and North Korea: How North Korea is Violating these Rules with its Operation of the Yodok Concentration CAMP.

Tom Theodore Papain

U.S. Institutionalized Torture with Impunity: Examining Rape and Sexual Abuse in Custody Through the ICTY JurisprudenCE. 126 Allison Rogne 
Abduction, Torture, Interrogation: An Argument Against Extraordinary RendiTION

Kaitlyn E. Tucker

United States and European Union approaches to the death penalty: America SHOULD CONSIDER A NEW PERSPECTIVE 155 Katie R Hill

Tudo DE NOVO NO FRONT: MONUSCO, UMA NOVA ERA NAS PEACEKEEPING OPERATIONS? .169 Priscila Fett

A ADMINISTRAÇÃo DE TERRITÓRIOS OCUPADOS: INDETERMINAÇÃO DAS NORMAS DE DIREITO INTERNACIONAL HUMANITÁRIO?. 184 João Henrique Ribeiro Roriz, Fabia Fernandes Carvalho Veçoso e Lucas da Silva Tasquetto

THE (IN)APPLICABILITY OF THE STATUTE OF REFUGEES TO ENVIRONMENTALLY DISPLACED PERSONS 197 Maria Cláudia da Silva Antunes de Souza e Lucas de Melo Prado

\section{Sistema Interamericano de Direitos Humanos}

A contribuição da Comissão Interamericana de Direitos Humanos para o acesso À jus-

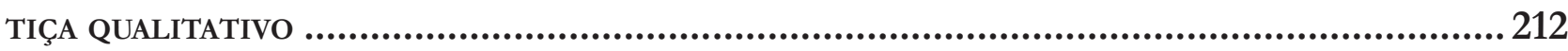
Márcio Antônio de Oliveira Filho, Ana Caroline Portes de Oliveira, Jéssica Galvão Chaves e Warlen Soares Teodoro

A executividade das sentenças da Corte Interamericana de Direitos Humanos no

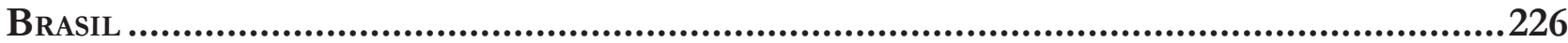

Augusto César Leite de Resende

A efetividade do ativismo jurídico transnacional no Sistema Interamericano de DiREITOS HuMANOS: UMA ANÁLISE A PARTIR DE CASOS CONTRA O BRASIL .................................238 Renata Mantovani de Lima e Lucélia de Sena Alves

O Processo e o Direito Coletivo no Sistema Interamericano de Direitos Humanos: UMA ANÁLISE COM BASE NA JURISPRUDÊNCIA INTERNACIONAL ...........................................250 Laercio Dias Franco Neto e Dafne Fernandez de Bastos 
CORTE INTERAMERICANA DE DIREITOS HUMANOS: OPINIÃo CONSULTIVA 4/84 - A MARGEM DE

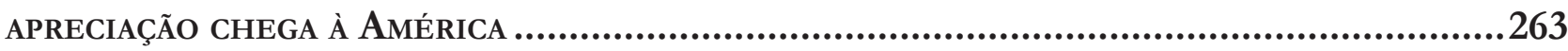

Paloma Morais Corrêa

A "PLENA" LIBERDADE DE EXPRESSÃo E OS DIREITOS HUMANOS: ANÁLISE DA JURISPRUDÊNCIA DA Corte InTeramericana de Direitos Humanos e o Julgamento da ADPF 130 281 Natália Paes Leme Machado

A proteção do meio ambiente no Sistema Interamericano de Direitos Humanos a parTIR DO DIREITO À EDUCAÇÃO.

Augusto César Leite de Resende

Parameters and procedures of the Inter-American System of Human Rights in CHILDREN'S RIGHTS VIOLATION LAWSUITS

Maria Guiomar da Cunha Frota e Pedro Alves Barbosa Neto

Poverty as a Violation of Human Rights: THE CASE OF STREET CHILDREN IN GUATEMALA AND BRAZIL

Paloma Morais Correa

\section{Proteção Internacional dos Direitos Humanos e o Direito Brasileiro}

A LEI N. 11.340/06 E SUAS REPERCuSSõES No CONTRATO INDIVIDUAL DE TRABALHo. Humberto Lima de Lucena Filho e Waldeny Pereira Filho

ORIENTAÇÃo SEXUAL E DISCRIMINAÇão NO AMBIENTE LABORAL

Glaucia Fernanda Oliveira Martins Batalha

NORMAS EDITORIAIS 


\title{
Corte interamericana de direitos humanos: opinião consultiva 4/84 - a margem de apreciação chega à América
}

\author{
Inter-american court of human rights: \\ advisory opinion 4/84 - the margin of \\ appreciation arrives at the american continent*
}

Paloma Morais Corrêa**

\section{Resumo}

O Movimento Internacional dos Direitos Humanos desafia o conceito clássico de soberania estatal. Em contrapartida, os argumentos em defesa da soberania representam obstáculos aos movimentos de universalização e regionalização dos direitos humanos. Este artigo baseou-se em análise qualitativa jurisprudencial, doutrinária e documental acerca do desenvolvimento de uma doutrina de deferência na supervisão internacional de direitos humanos - a margem de apreciação. Tal teoria foi criada pela jurisprudência da Corte Europeia de Direitos Humanos com o objetivo de preservar a discricionariedade dos Estados na implementação de normas internacionais de direitos humanos. $\mathrm{Na}$ jurisprudência do Sistema Interamericano, a margem de apreciação ganhou espaço na Opinião Consultiva 4/84, que discutia mudanças constitucionais no processo de naturalização de estrangeiros na Costa Rica. Este artigo tem como objetivo analisar o único momento no qual a Corte Interamericana de Direitos Humanos aplicou a teoria da margem de apreciação, teoria essa que, no continente Europeu, revela-se parte integrante do raciocínio jurídico. O estudo indica que a margem de apreciação, como mecanismo de defesa da soberania estatal, foi utilizada pelo Sistema Interamericano de forma mais cautelosa em relação àquela que tem sido observada no Sistema Europeu. Criticamente, demonstrar-se-á que a utilização da doutrina da margem de apreciação nas decisões dos tribunais internacionais revela a superficialidade do comprometimento das democracias liberais com os direitos humanos.

Palavras-chave: Soberania. Direitos humanos. Margem de apreciação.

* Recebido em 05/09/2013

Aprovado em 20/10/2013

** Mestre pela Universidade Federal do Rio Grande do Sul (2010) e London School of Economics and Political Science (2010). Foi professora no curso de Relações Internacionais da Universidade Federal de Pelotas. Atualmente, é Analista Técnica de Políticas Sociais no Ministério do Desenvolvimento Social e combate à Fome Email: paloma.correa@mds.gov.br.

\section{Abstract}

The International Human Rights Movement challenges the classical concept of state sovereignty. On the other hand, claims on sovereignty represent an obstacle to the universalisation and regionalisation of human rights. This article undertakes a qualitative analysis on jurisprudence, literature and documents concerning the development of a deference doctrine in international supervision of human rights - the margin of appreciation. This theory has been developed by the European Court of Human Rights in 
order to preserve the state discretion on implementing international human rights norms. In the Inter-American System, the margin of appreciation appeared in the Advisory Opinion 4/84, concerning a constitutional amendment to the naturalisation procedure in Costa Rica. This article aims to analyse the sole moment where the Inter-American Court of Human Rights has applied the margin of appreciation, a theory that constitutes an integral part in European judicial reasoning. The study indicates that the margin of appreciation as a mechanism to protect state sovereignty has been adopted by the Inter-American System in a more cautious fashion than by the European System. Critically, the article will demonstrate that while applying the doctrine of the margin of appreciation in their decisions, the international tribunals uphold the superficial commitment of liberal democracies to human rights.

Keywords: Sovereignty. Human rights. Margin of appreciation.

\section{INTRODUÇÃo}

O direito internacional dos direitos humanos desafia a base das relações internacionais, fundada no princípio da soberania dos Estados. Em contrapartida, o princípio da soberania estatal permanece como grande obstáculo para o Movimento Internacional dos Direitos Humanos. Prova disso é que os argumentos contrários à universalização e à regionalização dos direitos humanos no mundo estão, invariavelmente, baseados na necessidade de proteção da independência e autonomia dos Estados soberanos que compõem a comunidade internacional. As chamadas doutrinas de deferência na supervisão internacional dos direitos humanos nada mais são do que mecanismos de proteção da soberania dos Estados.

Dentre as doutrinas de deferência, destaca-se a margem de apreciação desenvolvida pela Corte Europeia de Direitos Humanos e que prega a discricionariedade dos Estados na implementação das legislações internacionais de direitos humanos. Na Europa, a doutrina da margem de apreciação é parte integrante do raciocínio jurídico da Corte Europeia de Direitos Humanos, sendo alvo de severas críticas por parte da doutrina especializada. Conforme entendimento de Charlesworth e Chinkin, "os Estados ocidentais desenvolveram as suas próprias formas de relativismo cultural na área dos di- reitos humanos, arguindo extensas margens de apreciação na implementação das suas obrigações, baseados em particularidades nacionais". ${ }^{1}$

Este estudo analisa a aplicação da doutrina da margem de apreciação pela Corte Interamericana de Direitos Humanos, bem como o desenvolvimento jurisprudencial dessa doutrina no Sistema Europeu. Com o objetivo de observar quais são os impactos observados no movimento de regionalização provenientes do emprego desse instrumento de preservação da soberania, analisou-se o parecer da Corte Interamericana na Opinião Consultiva 4/84, que trata das propostas de emenda aos dispositivos constitucionais relativos ao processo de naturalização na Costa Rica.

\section{A OPINIÃO CONSULTIVA 4/84 DA CORTE INTERAMERICANA DE DIREITOS HUMANOS}

Em 1983, a Corte Interamericana de Direitos Humanos recebeu do Governo da Costa Rica uma solicitação de Opinião Consultiva relativa a propostas de emendas aos dispositivos constitucionais que regiam a naturalização naquele país.

A solicitação costa-riquenha originou, em 19 de janeiro de 1984, a publicação da Opinião Consultiva 4/84, na qual a Corte Interamericana, pela primeira e única vez, fez referência, no seu parecer, à doutrina da margem de apreciação desenvolvida pela Corte Europeia de Direitos Humanos.

A requisição governamental solicitava a análise de compatibilidade das propostas de emenda aos Artigos 14 e 15 da Constituição da Costa Rica com a Convenção Americana de Direitos Humanos.

Abaixo, apresenta-se o texto constitucional original seguido das propostas de modificação em itálico:

\begin{abstract}
Artigo 14. São costa-riquenhos por naturalização:
Aqueles que adquiriram esse status em virtude de leis anteriores;

Nacionais de outros países da América Central, de boa conduta, que tenham residido ao menos um ano no país e que declarem perante o registro civil sua intenção de ser costa-riquenhos;
\end{abstract}

1 CHARLESWORTH, H., CHINKIN, C. The Boundaries of International Law: a feminist analysis. Manchester: Manchester University Press, 2000. p. 22. 
Hispânicos e ibero-americanos natos, que obtenham o certificado apropriado do registro civil, desde que tenham tido domicílio no país durante os anos anteriores ao requerimento;

Nacionais nativos de outros países da América Central, bispânicos e ibero-americanos com cinco anos de residência oficial no pais e que preencham os demais requisitos da lei;

Centro-americanos, hispânicos e ibero-americanos que não sejam natos e outros estrangeiros que tenham tido domicilio na Costa Rica por um período mínimo de cinco anos imediatamente anteriores ao requerimento de naturalização, de acordo com os requisitos legais;

Centro-americanos, hispânicos e ibero-americanos que não sejam natos e outros estrangeiros que tenham mantido residência oficial por um periodo mínimo de sete anos e que preencham os demais requisitos da lei;

Mulher estrangeira que mediante casamento com um costa-riquenho perca sua nacionalidade e que indique seu desejo de se tornar costa-riquenha;

Mulher estrangeira que mediante casamento com um costariquenho perca sua nacionalidade on que após dois anos de casamento com costa-riquenho e após o mesmo periodo de residência no país, indique seu desejo de assumir nossa nacionalidade;

Qualquer um que receba nacionalidade honorária da Assembleia Legislativa;

Artigo 15. Qualquer um que requeira naturalização deve previamente demonstrar evidências de boa conduta, deve demonstrar que possui uma ocupação conhecida e ou formas de subsistência e deve comprometer-se a residir regularmente na República.

Qualquer um que requeira naturalização deve previamente demonstrar evidências de boa conduta, deve demonstrar que possui uma ocupação conhecida e ou formas de subsistência, e deve saber falar, escrever e ler em espanhol. O requerente deve submeter-se a um exame compreensivo da história do país e seus valores bem como deve, ao mesmo tempo, comprometer-se a residir dentro do território nacional regularmente e jurar respeito à ordem constitucional da República.

Para fins de naturalização, domicílio implica residência e estável e efetiva conexão com a comunidade nacional, de acordo com as regulações estabelecidas por direito.

A proposta de emenda revoga este parágrafo do dispositivo, e inclui o seguinte: Os requerimentos e procedimentos de naturalização deverão ser estabelecidos por lei. ${ }^{2}$

A análise das propostas de emenda revela que elas impõem requisitos mais rígidos para a aquisição da nacionalidade costa-riquenha por naturalização. Por isso, a Corte Interamericana de Direitos Humanos foi solicitada a comparar o texto proposto com os seguintes artigos da Convenção Americana de Direitos Humanos,

2 COSTA RICA. Constituição Política da República, de 8 de novembro de 1949. a fim de determinar a compatibilidade da lei nacional com o Tratado Internacional.

Artigo 17. Proteção da Família

Parágrafo 4. Os Estados-partes devem adotar as medidas apropriadas para assegurar a igualdade de direitos e a adequada equivalência de responsabilidade dos cônjuges quanto ao casamento, durante o mesmo e por ocasião de sua dissolução. Em caso de dissolução, serão adotadas as disposições que assegurem a proteção necessária aos filhos, com base unicamente no interesse e conveniência dos mesmos.

Artigo 20. Direito à nacionalidade

Toda pessoa tem direito a uma nacionalidade.

Toda pessoa tem direito à nacionalidade do Estado em cujo território houver nascido, se não tiver direito a outra.

A ninguém se deve privar arbitrariamente de sua nacionalidade, nem do direito de mudá-la.

Artigo 24. Igualdade perante a lei

Todas as pessoas são iguais perante a lei. Por conseguinte, têm direito, sem discriminação alguma, à igual proteção da lei. ${ }^{3}$

O Governo da Costa Rica solicitou a manifestação da Corte Interamericana no que tange à compatibilidade das emendas propostas com os supracitados dispositivos da Convenção Americana de Direitos Humanos, questionando, especificamente, se as alterações legislativas afetariam os direitos à nacionalidade e à igualdade entre os cônjuges no território costa-riquenho.

No seu parecer, a Corte Interamericana analisou os requisitos de admissibilidade em relação ao Artigo 64 parágrafo $2^{\circ}$ e ao Artigo 29 da Convenção Americana de Direitos Humanos, que regem sobre a competência consultiva da Corte e sobre as questões relativas à interpretação, respectivamente. No mérito, manifestou-se relativamente ao direito à nacionalidade e ao princípio da não discriminação. ${ }^{4}$

\section{A MARGEM DE APRECIAÇÃo NO SISTEMA INTE- RAMERICANO}

$\mathrm{Na}$ análise do mérito, a Corte deliberou a respeito da discricionariedade dos Estados em relação à regula-

3 ORGANIZAÇÃO DOS ESTADOS AMERICANOS. Convenção Americana sobre Direitos Humanos, 22 de novembro de 1969. 4 CORTE INTERAMERICANA DE DIREITOS HUMANOS. Opinião Consultiva sobre propostas de emendas aos dispositivos constitucionais que regem a naturalização na Costa Rica, Opinião no 4/84. Parecer de 19 de janeiro de 1984. 
ção do direito à nacionalidade, fazendo, posteriormente, expressa referência à margem de apreciação quando se manifestou acerca do princípio da não discriminação, como se examinará a seguir.

Com relação ao direito à nacionalidade, além do Artigo 20 da Convenção Americana, também foram referidos os Artigos 19, da Declaração Americana de Direitos e Deveres do Homem, e 15 da Declaração Universal dos Direitos Humanos que estabelecem respectivamente:

Toda pessoa tem direito à nacionalidade que legalmente lhe corresponda, podendo mudá-la, se assim o desejar, pela de qualquer outro país que estiver disposto a concedê-la. ${ }^{5}$

1. Toda pessoa tem direito a uma nacionalidade.

2. Ninguém será arbitrariamente privado de sua nacionalidade, nem do direito de mudar de nacionalidade. ${ }^{6}$

A tarefa da Corte Interamericana era, naquele momento, analisar a compatibilidade das propostas de emenda constitucional da Costa Rica com os referidos textos legais - documentos internacionais de proteção aos direitos humanos - no tocante ao direito dos indivíduos à nacionalidade. ${ }^{7}$ Para tanto, em sua fundamentação, definiu nacionalidade como sendo "[...] o elo político e legal que liga uma pessoa a um determinado Estado com o qual se conecta através de laços de lealdade e fidelidade, proporcionando-lhe proteção diplomática por parte daquele Estado." ${ }^{8}$ Como primeiro argumento,

5 ORGANIZAÇÃO DOS ESTADOS AMERICANOS. Declaração Americana dos Direitos e Deveres do Homem, abril de 1948.

6 NAÇÕES UNIDAS. Declaração Universal dos Direitos Humanos, 12 de dezembro de 1948.

$7 \mathrm{Na}$ atualidade, o Direito Internacional Público considera a nacionalidade como um direito humano fundamental, pois segundo a reflexão de Hannah Arendt, "o primeiro direito humano é o direito a ter direitos", o que significa pertencer, pelo vínculo da cidadania, a algum tipo de comunidade juridicamente organizada e viver em uma estrutura na qual se é julgado pelo princípio da legalidade. Ainda de acordo com Hannah Arendt, a proteção ao direito à nacionalidade trata-se de um reflexo da experiência gerada no pós-Primeira Guerra Mundial em relação aos apátridas fruto dos regimes totalitários. Por essa razão, a jurisprudência norte-americana considerou inaceitável a privação da cidadania como sanção, pois como apontou a Suprema Corte dos Estados Unidos, “[...] no mundo contemporâneo, destituir alguém de sua cidadania é tendencialmente expulsá-lo do mundo, tornando-o supérfluo e descartável, a exemplo do que fez a experiência totalitária".

LAFER, Celso. A Reconstrução dos Direitos Humanos: um diálogo com o pensamento de Hannah Arendt. São Paulo: Companhia das Letras, 1998.

8 CORTE INTERAMERICANA DE DIREITOS HUMANOS. Opinião Consultiva sobre propostas de emendas aos dispositivos constitucionais que regem a naturalização na Costa Rica, Opinião n 4/84. Parecer de 19 mencionou a doutrina clássica, que impõe a discricionariedade estatal nos assuntos relacionados à atribuição de nacionalidade aos indivíduos, mas estabeleceu um contraponto ao lembrar que, atualmente, a discricionariedade estatal está limitada por assuntos relacionados à proteção dos direitos humanos, o que obriga à relativização da jurisdição estatal em relação às legislações internacionais. A esse respeito, na Opinião Consultiva em análise, manifestou-se a Corte da seguinte forma:

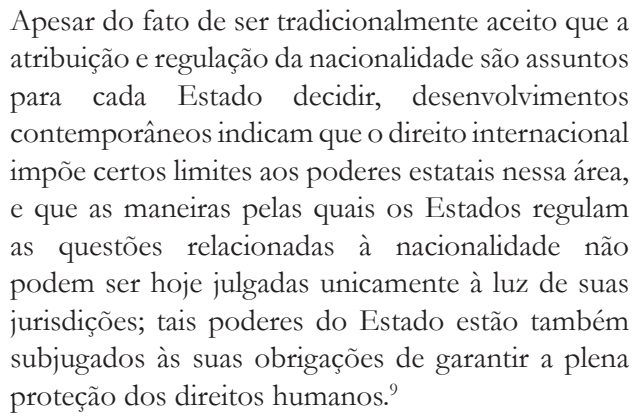

Ainda na fundamentação, a Corte expressa a necessidade de conciliação desses princípios impostos pelo direito internacional aos poderes do Estado com as questões que reconhecidamente recaem sob a esfera doméstica de cada Estado, como é o caso das regras estabelecendo a nacionalidade. Nesse sentido, contrapõe:

\begin{abstract}
Tendo em vista que é o Estado quem oferece a possibilidade de adquirir sua nacionalidade a pessoas que eram originalmente estrangeiros, é natural que as condições e procedimentos para sua aquisição devam ser governados primeiramente pelo direito doméstico daquele Estado. Desde que tais regras não entrem em conflito com normas superiores, é o Estado que confere a nacionalidade e quem está melhor habilitado para avaliar as condições que devam ser impostas para assegurar a existência de uma ligação efetiva entre aquele que requer a naturalização e os sistemas de valores e interesses da sociedade com a qual ele busca associar-se plenamente. Este Estado é também o mais indicado a decidir se tais condições foram satisfeitas. ${ }^{10}$
\end{abstract}

Conclusivamente, a Corte expõe que alguns problemas trazidos pelas propostas de emenda constitucional “[...] não são para serem consideradas por este Tribunal, pois recaem na categoria de assuntos reservados ao do-

de janeiro de 1984, p. 10.

9 CORTE INTERAMERICANA DE DIREITOS HUMANOS. Opinião Consultiva sobre propostas de emendas aos dispositivos constitucionais que regem a naturalização na Costa Rica, Opinião n 4/84. Parecer de 19 de janeiro de 1984 , p. 9.

10 CORTE INTERAMERICANA DE DIREITOS HUMANOS. Opinião Consultiva sobre propostas de emendas aos dispositivos constitucionais que regem a naturalização na Costa Rica, Opinião n ${ }^{\circ}$ 4/84. Parecer de 19 de janeiro de 1984, p. 9. 
mínio exclusivo das leis domésticas da Costa Rica". ${ }^{11}$

$\mathrm{Na}$ segunda parte da fundamentação, coube à Corte analisar as questões relativas à discriminação. Primeiramente, destacou que a noção de igualdade está ligada à dignidade da pessoa humana, sendo por isso inadmissível que seres humanos sejam submetidos a tratamentos diferentes que denotem a superioridade de qualquer grupo em relação aos demais. Seguindo esse raciocínio, considera ainda o fato de não ser toda e qualquer forma de diferença de tratamento que é classificada como discriminatória, pois nem toda diferença de tratamento é ofensiva à dignidade humana.

Fazendo expressa referência à Corte Europeia de Direitos Humanos, cita um caso em que este Tribunal determinou que "o tratamento discriminatório ocorre quando não possui objetivo nem justificativa razoável”. ${ }^{12}$ A ideia é a de que não se classifiquem as diferenças de tratamento aos indivíduos como discriminatórias por parte de um Estado quando elas estiverem baseadas em diferenças substanciais fáticas e desde que exista relação de proporcionalidade entre tais diferenças e os objetivos da norma legal em questão. Os objetivos, vale lembrar, não devem ser despóticos ou contrários à dignidade humana. $\mathrm{E}$ foi justamente ao considerar a proporcionalidade de possíveis restrições à dignidade da família em relação ao bem-estar público que a Corte Interamericana de Direitos Humanos, seguindo a referência já feita ao Tribunal Europeu de Direitos Humanos, aplicou a teoria da margem de apreciação na Opinião Consultiva 4/84. Sob o argumento de que é compatível com a natureza e o objetivo do direito à nacionalidade $\mathrm{O}$

11 CORTE INTERAMERICANA DE DIREITOS HUMANOS. Opinião Consultiva sobre propostas de emendas aos dispositivos constitucionais que regem a naturalização na Costa Rica, Opinião $n^{\circ} 4 / 84$. Parecer de 19 de janeiro de 1984, p. 9. (grifo nosso).

12 A Corte Interamericana aqui se referia ao caso relativo a certos aspectos das leis de uso da linguagem na educação da Bélgica, Caso Linguistico Belga, julgado pela Corte Europeia de Direitos Humanos em 1968. Neste caso, pais que falavam o idioma francês questionaram o sistema educacional belga que dividia o país em quatro regiões linguísticas. A Corte Europeia aceitou uma margem de apreciação conferida às Partes-contratantes, pois os Estados possuíam discricionariedade em relação à regulamentação do direito à educação garantido no Artigo $2^{\circ}$ do Protocolo (P1-2). A Corte argumentou ainda que essa necessidade de discricionariedade estatal era proveniente "da natureza do próprio direito conferido", ou seja, "do direito à educação, cuja regulação pode variar de acordo com o local e o tempo, conforme as necessidades e recursos da comunidade e dos indivíduos" CORTE EUROPEIA DE DIREITOS HUMANOS. Caso Linguístico Belga. Sentença de 23 de julho de 1968. procedimento privilegiado de naturalização para aqueles que, vistos objetivamente, possuem laços históricos, culturais e espirituais muito mais estreitos com o povo da Costa Rica, como são os Centro e Ibero-Americanos e Hispânicos, a Corte afirmou que:

[...] não há dúvida que pertence ao poder soberano da Costa Rica decidir quais patamares devem determinar a concessão ou negativa de nacionalidade aos estrangeiros que a requerem, e estabelecer certas diferenças razoáveis baseadas em diferenças fáticas que, vistas objetivamente, reconhecem que alguns requerentes possuem maior afinidade do que outros com os valores e interesses do sistema da Costa Rica [...] e que, portanto, a Corte está plenamente convencida da margem de apreciação que é reservada aos Estados para estabelecer os requisitos de aquisição da nacionalidade e determinar se estes foram satisfeitos. ${ }^{13}$

\section{EM DEBATE: A MARGEM DE APRECIAÇÃo E A INTERNALIZAÇÃO DOS TRATADOS INTERNACIONAIS DE DIREITOS HUMANOS}

Reconhecido é o fato de que a ideia de Direitos Humanos, vistos como uma ordem superior com a qual todos os Estados devam estar submetidos, desafia o conceito de soberania estatal. Foi justamente na tentativa de reconciliação do debate entre soberania e direitos humanos que a Corte Europeia de Direitos Humanos desenvolveu a Teoria da Margem de Apreciação. O objetivo era estabelecer uma forma de limitação jurisdicional em que certas áreas são deixadas à discricionariedade dos Estados contratantes. A doutrina emergiu principalmente quando a Corte teve de julgar valores morais conflitantes, bem como durante estados de exceção ou emergência. ${ }^{14}$

Significa dizer que uma margem de apreciação, ou
área de julgamento discricionário é permitida aos
Estados quando estes julgam existir uma necessidade
social e a natureza de uma resposta apropriada. A
noção da "margem de apreciação" baseia-se no fato
de que as autoridades nacionais estão numa posição
melhor do que um tribunal internacional para julgar
o que é necessário de acordo com as condições

13 CORTE INTERAMERICANA DE DIREITOS HUMANOS. Opinião Consultiva sobre propostas de emendas aos dispositivos constitucionais que regem a naturalizą̧ão na Costa Rica, Opinião $n^{\circ}$ 4/84. Parecer de 19 de Janeiro de 1984. p. 16. (grifo nosso).

14 CAVANAUGH, Kathleen. Policing the margins: rights protection and the European Court of Human Rights. European Human Rights Law Review, Londres, n.4, p. 422-444, 2006. 
locais. Em direito internacional público, ela oferece uma maneira de mediar a tensão entre a soberania estatal em relação às instituições internacionais e a necessidade de universalização dos patamares de direitos humanos. ${ }^{15}$

Trata-se de referência ao Princípio da Especialidade segundo o qual a distribuição de competências jurisdicionais deve ser realizada de acordo com a maior capacidade decisória das autoridades envolvidas. A capacidade decisória é avaliada conforme o nível de experiência com as situações do caso concreto. As autoridades nacionais, por estarem em posição mais próxima à realidade do conflito, estariam mais capacitadas a decidir. $\mathrm{O}$ princípio da subsidiariedade da jurisdição internacional em relação à jurisdição doméstica, bem como a noção de economia judicial, reforça a aplicação da doutrina. ${ }^{16}$

Por um lado, a margem de apreciação permite um nível de desvio cultural enquanto preserva o consenso geral; por outro, revela-se um empecilho à universalização. Os defensores da Teoria, como os juízes internacionais que a aplicam, pregam que a doutrina reconcilia a diversidade política, social, cultural e econômica dos Estados-membros. Os críticos, por sua vez, descrevem-na como "[...] uma teoria legalmente imprecisa, que desvaloriza direitos e liberdades consagrados na Convenção, causando impacto no exame e na proteção judicial.”17

Entre os argumentos favoráveis à aplicação da doutrina da margem de apreciação está o da vantagem institucional, uma vez que a capacidade decisória das autoridades nacionais é superior à dos órgãos internacionais, que via de regra carecem de recursos, informações, análise de dados e acesso à perícia técnica. Com relação a esse argumento, salienta-se que, se por esse motivo entende-se que deva ser o processo decisório mantido nas mãos dos atores nacionais, por outro lado são as cortes internacionais que possuem mais capacidade para interpretar as normas de Direito Internacional, razão pela qual se explica suas funções de supervisionar as decisões nacionais.

O correto equilíbrio entre deferência e supervisão, por isso, só será atingido por meio da combinação en-

15 FELDMAN, David. Civil Liberties and Human Rights in England and Wales. 2. ed. Oxford: Oxford University Press, 2002. p. 57.

16 BAKIRCIOGLU, Onder The Application of the Margin of Appreciation Doctrine in Freedom of Expression and Public Morality Cases. German Law Journal, v.8, n.7, p.711-734, 2007.

17 CAVANAUGH, Kathleen. Policing the margins: rights protection and the European Court of Human Rights. European Human Rights Law Review, Londres, n.4, p. 422-444, 2006. p. 422. tre discricionariedade para as autoridades nacionais e revisão pelas cortes internacionais. Outro argumento enfatizado na defesa da doutrina é o da valorização do princípio democrático. Esse pensamento reforça a ideia de que decisões importantes relacionadas a situações sociais não deveriam ser tarefa do Poder Judiciário. Assim, entende-se que, como os juízes não foram eleitos diretamente pelo povo, às sociedades deve ser conferida certa liberdade na adoção de arranjos sociais que reflitam seus desejos, valores e interesses, o que só poderia ser adquirido por meio de um processo democrático. ${ }^{18}$ Além disso, a demonstração de cautela por parte dos órgãos internacionais na atribuição de responsabilidade estatal por violação aos direitos humanos, adequada quando consideramos as consequências formais e informais advindas dessa divulgação (como sanções e retaliações no plano internacional, além do abalo à reputação do Estado), também advoga em favor da margem de apreciação.

Finalmente, a adoção da doutrina também é considerada positiva pelo fato de contribuir na cooperação entre as instituições nacionais e internacionais. Essa parceria facilitaria o processo de internalização das normas internacionais pelos atores domésticos. ${ }^{19}$ Nesse sentido, salientamos que o objetivo de um direito mundial, nas palavras de Delmas-Marty, certamente não é o de promover o desaparecimento dos Estados ou do direito nacional. Segundo a autora, "as instituições estatais permanecem indispensáveis para conter os interesses privados e organizar os direitos individuais e coletivos, como exemplifica a tragédia dos povos sem Estado para lhes representar". ${ }^{20}$

Autores contrários à aplicação da doutrina, contudo, ponderam que a margem de apreciação proporciona $\mathrm{O}$ desenvolvimento de um direito paralelo, criado pelos

18 SHANY, Yuval. Toward a General Margin of Appreciation Doctrine in International Law? European Journal of International Law, Florença, v.16, n.5, p. 907-940, 2005. Outro argumento referentemente a esta ideia do princípio democrático, entretanto, foi manifestada por Francesca Klug, ao afirmar que, “[...] em relação a Direitos Humanos, o papel do Judiciário é proteger as minorias da vontade da maioria, independentemente do quão impopular seja esta minoria". KLUG, Francesca. Values for a Godless Age: The story of the United Kingdom's Bill of Rights. Londres: Penguin Books, 2000, p. 184. Difícil imaginar qualquer valoração do princípio democrático capaz de contrapor tal argumento.

19 SHANY, Yuval. Toward a General Margin of Appreciation Doctrine in International Law? European Journal of International Law, Florença, v.16, n.5, p. 907-940, 2005.

20 DELMAS-MARTY, M. Trois défis pour um droit mondial. Paris: Éditions Du Seuil, 1998. p. 173. 
magistrados, e que a discricionariedade conferida aos juízes na aplicação das normas internacionais dificultaria a efetividade dessas normas. Salientam, ainda, que essa prática comprometeria a imparcialidade do Judiciário em razão da possibilidade de supervalorização dos interesses do Estado em relação às normas internacionais de proteção aos direitos humanos.

A aplicação da doutrina em relação a normas de jus cogens, que não admitiriam derrogação dada à sua natureza fundamental de um valor internacional a ser protegido, também tem sido alvo de muitas críticas. Outra objeção está relacionada aos custos da ambiguidade normativa gerada pelo uso da margem de apreciação, que tende a deixar os indivíduos mais vulneráveis às ações do Estado, além de afetar indiretamente a outros Estados. ${ }^{21}$

Delmas-Marty apresenta as técnicas jurídicas da margem de interpretação ou margem nacional de apreciação como responsáveis pela redução do universalismo e destaca como principal dificuldade a conciliação, no contexto das relações entre os indivíduos, dos ideais de igualdade e democracia em contraposição à heterogeneidade que envolve a noção de Estado soberano (diferentes em termos de quantidade de população e poder econômico, bem como em termos de respeito ao ideal democrático).

A ideia de instituições públicas mundiais confronta
diretamente com o conceito de soberania,
enquanto que o de sociedade civil mundial
conduz ao de cidadania do mundo [...]. As noções
de subsidiariedade ou de margem nacional de
apreciação possuem o mérito de terem sido criadas
pela prática, mas o inconveniente de possuírem
origens mais políticas do que jurídicas, e de não
terem sido definidas com suficiente rigor [.....$^{22}$

\subsection{A técnica de utilização da doutrina no siste- ma europeu}

Referentemente ao método utilizado pela Corte Europeia de Direitos Humanos em seus julgamentos, a margem de apreciação poderá ser aplicada quando da análise da proporcionalidade da medida que restringe o direito. Assim, primeiramente a Corte analisa se houve

21 SHANY, Yuval. Toward a General Margin of Appreciation Doctrine in International Law? European Journal of International Law, Florença, v.16, n.5, p. 907-940, 2005.

22 DELMAS-MARTY, M. Trois défis pour um droit mondial. Paris: Éditions Du Seuil,1998, p. 176. interferência no direito. Em caso afirmativo, o próximo passo será a ponderação da legitimidade do objetivo perseguido pelo governo em questão. Em seguida, a Corte fará um exame de legalidade da restrição, quando haverá a averiguação se ela se encontra prescrita por direito. Finalmente, a Corte estabelece o exame de proporcionalidade da restrição, em que as duas principais perguntas a serem respondidas são: o objetivo legítimo poderia ter sido atingido por meio menos intrusivo? A interferência causa ao detentor do direito um prejuízo considerado suficientemente sério a ponto de superar qualquer benefício que aquela interferência venha a atingir em busca do objetivo? É nesta fase que a Corte poderá aplicar a margem de apreciação. ${ }^{23}$

A doutrina da margem de apreciação reflete noções de subsidiariedade, revelando confiança no Artigo $1^{\circ}$ da Convenção Europeia de Direitos Humanos (CEDH), de que os Estados contratantes comprometem-se a assegurar, dentro de suas jurisdições, os direitos e as liberdades postulados na Convenção, culminando com o exercício, por parte da Corte Europeia, de um judicial self-restraint. Nesse sentido, o Tribunal Internacional pode conceder uma margem de apreciação para o Estado tanto em relação a obrigações positivas, quanto negativas, mas o órgão tem se demonstrado relutante em analisar casos em que a alegação é de violação em abstrato da Convenção por parte do Direito nacional. Em vez disso, “a Corte prefere analisar se houve interferência no direito em relação a um caso particular". ${ }^{24}$

Há diferentes tipos de normas que proporcionam a aplicação da margem de apreciação: existem as que necessitam de um juízo de valor subjetivo, também chamadas de cláusulas de exceção ou de limitação. Essas normas incluem no seu texto elementos, como "necessidade", "proporcionalidade", "excessivamente", "boa-fé", "razoáveis", que demandam escolhas políticas baseadas nas circunstâncias específicas da realidade a que se submetem no caso concreto. Por isso, são facilmente acusadas de reduzirem a segurança jurídica, pois sua aplicação depende do bom-senso do julgador. Há também as normas discricionárias, que são as que fa-

23 SAMUELS, Harriet. Methodological Approaches by the Courts to the Human Rights Act 1998. Examples of the Convention's Application. Some Introductory Principles. Faculdade de Direito da Universidade de Westminster. Londres, 7 de novembro de 2006. [aula]

24 Observa-se, aqui, a importância do efeito da decisão para o caso concreto. DELMAS-MARTY, M. Trois défis pour um droit mondial. Paris: Éditions Du Seuil, 1998, p. 424. 
zem referência ao poder discricionário do Estado para sua aplicação. Em geral, ampla margem de apreciação é conferida aos Estados na regulamentação e implementação das normas internacionais discricionárias no interior dos seus territórios. Por fim, há as normas que preveem obrigações de resultado, de forma a proporcionar aos Estados uma margem de discricionariedade em relação aos meios empregados para atingir o fim. ${ }^{25}$

O reconhecimento de uma área de apreciação em favor dos órgãos administrativos do Estado vem a ser a impossibilidade de substituição, pelo Judiciário, da decisão tomada pela administração pública ao eleger uma das várias soluções que se apresentam para o caso. Nessas situações, teria a administração pública "prerrogativas de avaliação", conforme Hans Julius Wolf, que se justificam pelo fato de estarem os órgãos administrativos mais próximos dos problemas e por isso melhor aparelhados para resolvê-los. A decisão administrativa final, portanto, que se estabelecesse dentro dessa área de apreciação, não seria passível de modificação ou substituição por parte do controle judicial. ${ }^{26}$

\section{A MARGEM DE APRECIAÇÃO NA JURISPRUDÊN- CIA DA CORTE EUROPEIA DE DIREITOS HUMANOS}

A doutrina da margem de apreciação foi introduzida pela Corte Europeia de Direitos Humanos em vários casos, tendo sido desenvolvida pela jurisprudência dos órgãos de supervisão internacional de Estrasburgo sem estar explicitamente mencionada em nenhuma parte da Convenção. Sua aplicação, contudo, ocorre juntamente com alguns dispositivos específicos da Convenção Europeia de Direitos Humanos, como os Artigos 14 e 15, que declaram, respectivamente, a proibição à discrimi-

25 SHANY, Yuval. Toward a General Margin of Appreciation Doctrine in International Law? European Journal of International Law, Florença, v.16, n.5, p. 907-940, 2005.

26 Com relação a controle judicial, a doutrina e a jurisprudência brasileiras diferenciam a aplicação de conceitos jurídicos indeterminados e o poder discricionário. "Conceitos jurídicos indeterminados são conceitos empíricos, de valor ou normativos, que exigem do intérprete ou do aplicador da norma uma apreciação em termos valorativos. Estes estariam sujeitos a um controle jurisdicional mais amplo, que se observa tanto no aspecto formal quanto no material. Já o poder discricionário se submete a um controle judicial restrito, que se revela unicamente do ponto de vista formal, ausente o exame de mérito da medida". SILVA, Almiro Couto e. Poder Discricionário no Direito Administrativo Brasileiro. Revista de Direito Administrativo, Rio de Janeiro, v.179, n.80, p. 51-92, jan./jun.1990. p. 59. nação e a possibilidade de decretação de estado de emergência. Além desses dispositivos, a aplicação da margem de apreciação na jurisprudência europeia também pode ser observada em conjunto com as chamadas cláusulas de acomodação ou limitação, que são justamente as que permitem derrogação ao direito protegido, de acordo com as condições estabelecidas no parágrafo $2^{\circ}$ de cada artigo.

Os principais artigos da Convenção Europeia invocados nesse sentido foram o Artigo $8^{\circ}$ (direito à privacidade e à família); os Artigos 9, 10 e 11 (liberdades de religião, expressão, assembleia e associação); e o Artigo $2^{\circ}$ do $4^{\circ}$ Protocolo, que rege a liberdade de movimento ou residência. Dentre as condições que autorizariam a interferência estatal nesses direitos do indivíduo, estariam a anterioridade, ou seja, a exigência de que a interferência fosse prescrita ou autorizada por direito; que fosse legítima, no sentido de necessária para garantir a segurança nacional, a segurança pública, o bem-estar econômico do país, a prevenção da desordem ou crime, a proteção da saúde e da moral ou a proteção dos direitos e liberdades alheios; e, ainda, que a dita interferência estatal fosse necessária em uma sociedade democrática. Destaca-se aqui o aspecto eminentemente político desta última condição. ${ }^{27} \mathrm{~A}$ margem de apreciação pode ser entendida como efeito da interpretação das limitações que podem ser concedidas aos direitos do homem, quando tais direitos não estão bem definidos no texto legislativo internacional, ou quando admitem restrições a título temporário ou permanente. ${ }^{28}$

Mireille Delmas-Marty resume o conflito imposto ao juiz supranacional na sua tarefa de interpretar e aplicar uma Convenção relativa aos direitos do homem: “[...] mais do que um mero intérprete do Tratado Internacional, àquele magistrado será dado o poder de confrontar a Convenção com a norma de direito interno, e dessa forma, influenciar e predeterminar o direito doméstico, indicando inclusive, alguns limites a serem respeitados

27 DEL MORAL, Ignacio de la Rasilla. The Increasingly Marginal Appreciation of the Margin of Appreciation Doctrine. German Law Journal, v.7, n.6, p. 611-624, 2006.

28 As circunstâncias que ensejariam restrição temporária aos direitos dos cidadãos seriam aquelas "[...] relacionadas à necessidade de proteger a vida da nação"; já as restrições permanentes estariam "[...] ligadas à manutenção da ordem pública, como a prevenção de infrações, a proteção da moral pública, da autoridade e imparcialidade do judiciário, o bem-estar econômico do país, etc". DELMASMARTY, M. Trois défis pour um droit mondial. Paris: Éditions Du Seuil, 1998. p. 88. 
pelo legislador nacional". ${ }^{29}$ Temos, assim, um exemplo da interferência da jurisdição internacional de proteção aos direitos humanos no interior dos Estados soberanos.

George Letsas identifica dois conceitos diferentes no uso da doutrina da margem de apreciação: o substancial, que contrapõe os direitos individuais ao interesse público; e o estrutural, relacionado com os limites impostos pela soberania estatal aos objetivos de universalização perseguidos por um sistema judicial internacional. $\mathrm{O}$ conceito substancial requer a aplicação, por parte do Tribunal Internacional, do teste de proporcionalidade referido acima para estabelecer se a autoridade nacional violou um direito individual protegido pela Convenção ou se, ao contrário, agiu dentro de sua margem de apreciação, nesse caso, não haveria violação ao direito. O conceito estrutural reforça o caráter subsidiário do tribunal internacional, invocando-o a deferir a decisão para as autoridades nacionais. ${ }^{30}$

No caso Handyside v Reino Unido, o foco foi a discussão do que seria necessário para a proteção da moral social com relação à liberdade de expressão protegida pelo Artigo 10 da Convenção Europeia e a ação do Governo britânico em banir a publicação de um livro sob alegação de obscenidade. Dessa vez, a margem de apreciação foi introduzida pela Corte Europeia da seguinte forma:

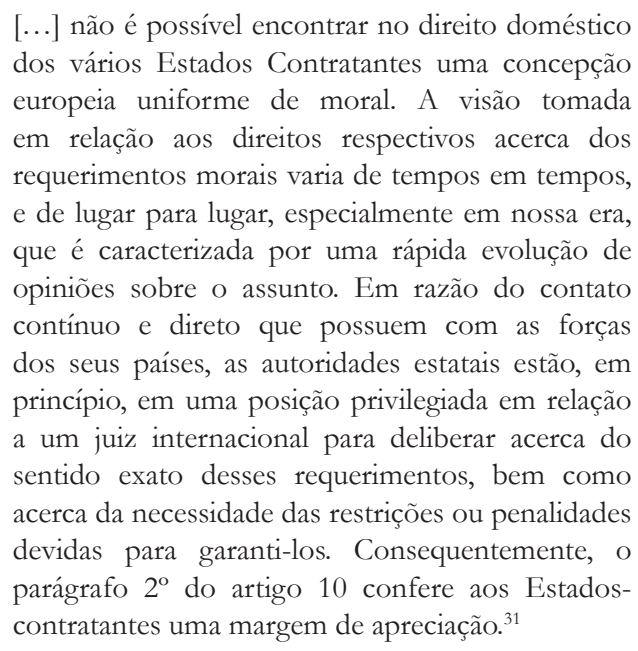

29 DELMAS-MARTY, M. Trois défis pour um droit mondial. Paris: Éditions Du Seuil, 1998, p. 87.

30 LETSAS, George. Two Concepts of the Margin of Appreciation. Oxford Journal of Legal Studies, Oxford, v.26, n.4, p.705-732, 2006. 31 CORTE EUROPEIA DE DIREITOS HUMANOS. Handyside v Reino Unido. Sentença de 7 de dezembro, de 1976, parágrafo 48. A ausência de uma concepção uniforme de moral na Europa voltou justificar a utilização da margem de apreciação em favor do Estado no caso Muller v Suiça, em 1991. Novamente, o direito à liberdade de expressão foi confrontado com a noção de obscenidade.
Outro exemplo é trazido pelo caso Otto Preminger Institute v Austria, em que foram postas em discussão a liberdade religiosa e a liberdade de expressão positivadas nos Artigos $9^{\circ}$ e 10 da Convenção, respectivamente. Esse caso versava sobre a proibição do filme $V$ isions of ecstasy por ser considerado ofensivo à religião Católica.

Uma vez que não há como discernir consenso na Europa da significância da religião na sociedade, é impossível definir compreensivamente qual interferência no discurso religioso é permissível. Certa margem de apreciação é, portanto, a ser deixada às autoridades nacionais para que avaliem a existência e extensão da necessidade de tal interferência $[\ldots]^{32}$.

A liberdade de expressão voltou a ser sede de discussão no caso Wingrove $v$ Reino Unido, que resultou de uma recusa, em 1989, do órgão britânico de classificação de filmes, em lançar o certificado de classificação do filme Visions of ecstasy sob a alegação de que infringiria a lei inglesa de blasfêmia. O produtor do filme argumentou que essa recusa violava os seus direitos de liberdade de expressão. Revendo o mérito do caso, a Corte afirmou:

[...] em questões passíveis de ofender convicções pessoais íntimas dentro da esfera da moral ou, especialmente da religião, o Estado contratante possui uma larga margem de apreciação para 'regular' a liberdade de expressão [...]. Tendo em vista a preservação do alto limiar de profanação presente na definição de ofensa por blasfêmia perante o direito inglês, bem como a margem de apreciação do Estado nessa área, as razões dadas para justificar as medidas tomadas podem ser consideradas relevantes e suficientes para os fins do $\$ 2^{\circ}$ do artigo 10 . Além disso, tendo ela própria assistido ao filme, a Corte concluiu que as decisões das autoridades nacionais não podem ser ditas arbitrárias ou excessivas. ${ }^{33}$

Observa-se que parece haver hierarquia de direitos em relação a qual amplitude da deferência conferida por parte da Corte Europeia de Direitos Humanos difere. Assim,

32 CORTE EUROPEIA DE DIREITOS HUMANOS. OttoPreminger Institute v Austria, Sentença de 7 de dezembro de 1976, parágrafo 48.

33 CORTE EUROPEIA DE DIREITOS HUMANOS. Wingrove $v$ Reino Unido. Sentença de 25 de Novembro de 1996, parágrafo 58. Essa passagem foi repetida no julgamento do caso Murphy $v$ Irlanda (2004), relativo à proibição de transmissão de um anúncio televisivo por parte da Comissão Irlandesa Independente de Rádio e Televisão. A Corte ratificou a alegação do governo irlandês de que a proibição destinava-se a garantir o respeito pelas doutrinas e crenças religiosas dos outros, de forma que "o objetivo perseguido pela medida era o da manutenção da ordem pública e da segurança, juntamente com a proteção dos direitos e liberdades do público em geral". LETSAS, George. Two Concepts of the Margin of Appreciation. Oxford Journal of Legal Studies, Oxford, v. 26, n. 4, p.705-732, 2006. p. 726. 
enquanto a liberdade de imprensa, ou o discurso político, devido à importância que possuem para as sociedades democráticas, constituem fatores que restringem a discricionariedade nacional, o elemento da moral pública ou privada permanece mantendo a margem de apreciação mais abrangente. Discursos de cunho político que ferem a liberdade democrática, por exemplo os que fazem apologia ao Holocausto, ou à ideologia racista, têm gerado a restrição da aplicação da margem de apreciação em favor da imposição de altos requerimentos de direitos humanos, como observado nos casos Kubnen v República Federal da Alemanha, de 1988, e Jersild v Dinamarca, de $1994 .{ }^{34}$

Dentre os exemplos da utilização dessa Doutrina no continente europeu, surgem também os casos relacionados aos direitos dos cidadãos transexuais, em que inicialmente a Corte sustentou "[...] não haver abordagem comum na Europa", e as decisões a esse respeito, inconsistentes, favoreceram aos Estados. ${ }^{35}$ Os casos envolvendo indivíduos transexuais versam, principalmente, em torno dos Artigos $8^{\circ}$ e 10 da Convenção (direito ao respeito à privacidade e à vida em família, e à liberdade de expressão), bem como em relação ao conflito dos direitos assegurados pelo Artigo $10 \mathrm{com}$ aqueles constantes no parágrafo $2^{\circ}$ do mesmo artigo. Esse parágrafo trata das restrições e condições ao exercício dessas liberdades em função da moralidade social e da segurança pública. Alguns desses casos são: Rees v Reino Unido (1986), Cossey $v$ Reino Unido (1990), B v Franca (1992), Sheffeeld e Horsham $v$ Reino Unido (1998), Goodwin v Reino Unido (2002). Na maior parte dos casos citados, a Corte deveria analisar a atuação dos governos nacionais referentemente à negativa de concessão ao cidadão transexual do direito a um novo registro de nascimento civil (em que constasse o novo sexo), de forma que o cidadão ficava, também, impedido de se casar com pessoas de sexo igual ao que ele possuía no momento de seu nascimento.

O Artigo 12 da Convenção Europeia garante o direito ao casamento entre homens e mulheres. A evolução do

34 Os casos Lingens v Áustria (1986) e Castells v Espanba (1992) exemplificam, respectivamente, julgamentos em que a Corte Europeia de Direitos Humanos defrontou-se com o direito à liberdade de imprensa e à liberdade de debate político. Em ambos, a margem conferida aos Estados foi restringida em favor do direito protegido pela Convenção. BAKIRCIOGLU, Onder. The Application of the Margin of Appreciation Doctrine in Freedom of Expression and Public Morality Cases. German Law Journal, v.8, n.7, p.711-734, 2007. 35 BAKIRCIOGLU, Onder. The Application of the Margin of Appreciation Doctrine in Freedom of Expression and Public Morality Cases. German Law Journal, v.8, n.7, p.711-734, 2007. p. 712. pensamento dos juízes europeus em relação aos direitos dos cidadãos transexuais pode ser resumida da seguinte forma: em Rees havia a preocupação com a ausência de bases comuns entre os Estados-contratantes acerca do assunto, quatro anos mais tarde, quando do julgamento de Cossey, a mesma justificativa foi adotada para decidir que "[...] não havendo consenso acerca do status que possuiriam os transexuais, essa era uma área na qual os Estados gozavam de uma larga margem de apreciação". ${ }^{36}$ Oito anos depois, a Corte salientou aspectos de ordem científica, legal, moral e social no julgamento de Sheffield e Horsham, no qual uma decisão em favor dos requerentes foi novamente negada, mas com votação bem mais divergente daquela que se tinha observado entre os juízes no julgamento de Rees.

Finalmente, em 2002, a jurisprudência europeia muda radicalmente no julgamento de Goodwin e I v Reino Unido, quando a Corte decidiu de forma unânime em favor dos requerentes. Essa diferença de opinião foi justificada pela Corte Europeia com base nas "[...] tendências internacionais de aceitação social dos transexuais", bem como no "[...] reconhecimento legal de uma nova identidade sexual após a operação de mudança de sexo a qual esses indivíduos submetiam-se". ${ }^{37}$

Em 2002, no julgamento de Frette v França, a Corte deparou-se com nova denúncia de discriminação contrária ao Artigo 14 da Convenção, mas dessa vez relativa à orientação sexual do requerente. $O$ caso versava sobre a negativa por parte do governo francês de autorizar a adoção de uma criança por um casal homossexual. Em sua decisão, favorável ao Estado, a Corte argumentou que "[...] em áreas onde havia pouco consenso entre os Estados-membros do Conselho da Europa e que em geral o direito estava ainda em um estágio de transição, uma larga margem de apreciação deveria ser deixada às autoridades de cada Estado". 38

\section{O multiculturalismo e a margem de APRECIAÇÃO}

A unificação da proteção aos direitos humanos encontra obstáculos também nas questões referentes ao

36 CORTE EUROPEIA DE DIREITOS HUMANOS. Cossey $v$ Reino Unido. Sentença de 27 de setembro, de 1990, parágrafo 40. 37 CORTE EUROPEIA DE DIREITOS HUMANOS, Goodwin $v$ Reino Unido. Sentença de 11 de julho de 2002, parágrafo 74.

38 CORTE EUROPEIA DE DIREITOS HUMANOS. Frette $v$ França. Sentença de 11 de julho, de 2002, parágrafo 36. 
relativismo cultural, que "[...] questiona a validade da fonte da regra moral", requerendo, ao mesmo tempo, que "[...] sejam as normas de direitos humanos interpretadas com sensibilidade às especificidades culturais do Estado em particular". ${ }^{39} \mathrm{O}$ dever de respeito ao multiculturalismo vem expresso em vários documentos de proteção aos direitos humanos, como no Artigo 27 da Declaração Universal de Direitos Humanos, no Artigo 15 (1) do Pacto Internacional dos Direitos Econômicos, Sociais e Culturais ou no Artigo 27 do Pacto Internacional de Direitos Civis e Políticos, e se traduz no direito de qualquer um de fazer parte da vida cultural e no direito de os grupos minoritários gozarem sua própria cultura.

O estabelecimento de direitos humanos internacionais capazes de limitar as exceções baseadas em argumentos culturais requer o reconhecimento de valores que conectam as culturas diferentes. Nesse sentido, o alerta de que "[...] o apelo à proteção cultural pode mascarar opressão, injustiça e impotência". ${ }^{40}$ Quando autores, como McGoldrick, afirmam que "[...] a ideologia multicultural tem sido opressiva à luta por igualdade nas esferas de gênero, raça, etnia e sexualidade", da mesma forma que há o entendimento de que “[...] a preocupação com cultura seja uma distração ao combate do tratamento desigual, da discriminação e da injustiça", ${ }^{41}$ deve-se reforçar a principal ideia da universalização dos direitos humanos, qual seja: a da dignidade humana como valor comum. $\mathrm{O}$ assunto, entretanto, é polêmico, o que se justifica pelo fato de que "[...] direitos culturais estão frequentemente respaldados por argumentos baseados em dignidade ou autonomia", ${ }^{42}$ de forma que a aplicação da margem de apreciação em casos em que há o apelo ao respeito da identidade cultural do Estado em questão ensejará debate, inegavelmente.

No contexto da discussão acerca da legitimidade de dissolução de partidos políticos em países democráticos, a Corte Europeia de Direitos Humanos analisou dois casos envolvendo a Turquia. Nos casos do Partido Refah e do Partido Comunista Unido da Turquia, as mudanças radicais de entendimento da Corte podem ser justi-

39 MCGOLDRICK, Dominic. Multiculturalism and its Discontents. Human Rights Law Review, Oxford, v.5, n.1, p. 27-56, 2005. p. 7. 40 MCGOLDRICK, Dominic. Multiculturalism and its Discontents. Human Rights Law Review, Oxford, v.5, n.1, p. 27-56, 2005. p. 7. 41 MCGOLDRICK, Dominic. Multiculturalism and its Discontents. Human Rights Law Review, Oxford, v.5, n.1, p. 27-56, 2005. p. 8. 42 MCGOLDRICK, Dominic. Multiculturalism and its Discontents. Human Rights Law Review, Oxford, v.5, n.1, p. 27-56, 2005. p. 9. ficadas com base nos momentos históricos nos quais os casos foram julgados, respectivamente em 2003 e 1998, revelando, assim, o relativismo temporal inerente à doutrina da margem de apreciação. ${ }^{43}$

\section{As SITUAÇÕES DE EMERGÊNCIA E A MARGEM DE APRECIAÇÃO}

Da mesma forma, a doutrina da margem de apreciação é utilizada como justificadora da não intromissão da Corte Europeia em assuntos relacionados às derrogações dos direitos conferidos pela Convenção Europeia de Direitos Humanos em tempo de guerra ou estado de emergência, conforme previsão do Artigo 15, que pode ser traduzida como adicional e codificada margem de apreciação. A derrogação só é permissível, em qualquer caso, quando um Estado contratante vivencia situação excepcional de crise ou de emergência que afeta a população inteira e constitui ameaça à organização da vida da comunidade que compõe o país. Para fazer jus ao direito, o Estado precisa pronunciar publicamente sua intenção de invocar derrogação. Precisa demonstrar que "a emergência pública é atual ou iminente, que ameaça a vida da nação, e qualquer ação tomada deve ser proporcional, temporária e consistente com suas obrigações de Direito Internacional, bem como não pode interferir com direitos não derrogáveis". ${ }^{44}$

No caso Lawless (Lawless v Irlanda), a Corte deparou-se com a situação de determinar se a situação de emergência de fato existia. O caso dizia respeito à detenção de um cidadão sob suspeita de fazer parte do IRA (Exército Republicano Irlandês), sem que um processo tivesse sido instaurado. Tal detenção foi permitida de acordo com o Ato Irlandês de Ofensas contra o Estado de 1940, que autorizava, em seguimento a uma declaração de emergência por parte do governo, a prisão de suspeitos em envolvimento com atividades prejudiciais à paz, à ordem e à segurança do Estado. A primeira de-

43 BOYLE, Kevin. Human Rights, Religion and Democracy: The Refah Party Case. Essex Human Rights Review, Essex, v.1, n.1, p.1-16, julho, 2004. Disponível em: <http://projects.essex.ac.uk/EHRR/ archive/> Acesso em: 24 out. 2006.

44 Enfatiza-se, portanto, a positivação da impossibilidade de violação das normas cogentes de Direito Internacional, ainda que durante o estado de emergência. CAVANAUGH, Kathleen. Policing the margins: rights protection and the European Court of Human Rights. European Human Rights Law Review, Londres, n.4, p.422-444, 2006. p. 436. 
claração expressa a respeito da margem de apreciação no contexto de estado de emergência foi feita pela Corte Europeia no julgamento do caso Irlanda v Reino Unido:

Recai em primeiro lugar a cada Estado contratante, com sua responsabilidade pela "vida da nação", determinar se esta vida está ameaçada por uma 'emergência pública' e, estando, o quanto longe será necessário ir na tentativa de reverter a emergência. Em razão de seu direto e contínuo contato com as necessidades do momento, as autoridades nacionais estão, a princípio, em melhor posição do que um juiz internacional para decidir tanto sobre a presença da dita emergência quanto sobre a natureza e oportunidade das derrogações necessárias para evitá-la. Nessa questão o artigo 15(1) deixa às autoridades uma larga margem de apreciação. ${ }^{45}$

No caso Brogan v Reino Unido, de 1989, a Corte entendeu que o Reino Unido, ao manter suspeitos de terrorismo detidos sem supervisão judicial por extensos períodos, ${ }^{46}$ havia violado o artigo $5^{\circ}$ (3) da Convenção Europeia de Direitos Humanos, que estabelece que "aquele que for preso ou detido legalmente deve ser prontamente levado a juízo ou levado a julgamento dentro de um tempo razoável, ou aguardar julgamento em liberdade". ${ }^{47}$

Outro foi o julgamento da Corte em 1993, no caso Brannigan e McBride v Reino Unido. No curso deste episódio, os reclamantes foram presos e detidos de acordo com o Ato (de Provisões Temporárias) de Prevenção ao Terrorismo de 1984. Os reclamantes argumentaram que o extenso período de detenção não poderia estar basea-

45 CORTE EUROPEIA DE DIREITOS HUMANOS. Irlanda Reino Unido. Sentença de 18 de janeiro de 1978, parágrafo. 207.

46 Em 1974, o Parlamento britânico promulgou o Ato de Prevenção ao Terrorismo (provisões temporárias). Em setembro e outubro de 1984, 4 indivíduos — suspeitos de serem membros do IRA — foram presos de acordo com a seção 12 do Ato e foram levados para centros de detenção. Após terem sido interrogados pelos períodos de 4 a 6 dias, eles foram liberados sem acusação. A seção 12 do Ato autorizava a polícia a deter qualquer pessoa suspeita de terrorismo pelo prazo de 48 horas, podendo haver autorização para estender esse período em até 5 dias. Foi o que ocorreu no caso Brogan, de forma que as prisões prolongadas foram, de acordo com a legislação britânica, legais. As quatro pessoas que foram submetidas à prisão prolongada alegaram perante a Corte Europeia de Direitos Humanos que a Grã-Bretanha havia violado o Artigo $5^{\circ}$ da Convenção, principalmente devido à ausência de controle judicial das prisões. Embora a Comissão tivesse opinado que apenas as detenções mais longas violavam o Artigo $5^{\circ}$ (3), a Corte entendeu que os quatro casos importaram em violação do mencionado artigo. TANCA, Antonio. Human Rights, Terrorism and Policy Custody: The Brogan Case. European Journal of International Law, Florença, v.1, n.1, p.269-277, 1990.

47 CONSELHO DA EUROPA. Convenção para a Proteção dos Direitos Humanos e Liberdades Fundamentais, de 4 de novembro de 1950. do no que era "[...] estritamente requerido pelas exigências da situação". Apesar disso, a Corte decidiu que os requerimentos perante o Artigo 15 haviam sido satisfeitos e, além do mais, aceitou o argumento estatal de que a detenção por extensos períodos e sem supervisão judicial era "[...] estritamente requerida pelas exigências da situação". Para justificar a divergência entre os dois julgamentos, a Corte explicou que "[...] as dificuldades de investigar e processar o crime de terrorismo faz surgir a necessidade de um extenso período de detenção que não estaria sujeito a controle judicial [...]" ${ }^{48}$

Como exemplo de rara ocasião em que a Corte admitiu ter um Estado excedido a sua margem de apreciação durante situação excepcional, cita-se o caso $A k$ soy v Turquia, de 1996. Em 1990, a Turquia notificou o Conselho da Europa de sua intenção de derrogar os Artigos $5^{\circ}, 6^{\circ}, 8^{\circ}, 10,11$ e 13 . A extensão e gravidade do terrorismo na Turquia, em especial no sudeste, e o alto preparo técnico das organizações terroristas da região foram as justificativas apresentadas pelo Estado turco para a inexistência de supervisão judicial durante a custódia policial dos suspeitos. Embora reconhecendo haver emergência pública ameaçando a vida da nação, a Corte examinou se as exigências da situação ensejariam interferência nos direitos do reclamante conforme o Artigo $5^{\circ}(3)$. A decisão foi a de que os direitos do indivíduo haviam sido violados, e que a interferência estatal no caso havia sido arbitrária. ${ }^{49}$

Em comparação com o caso analisado anteriormente, em que o Estado em questão era a Irlanda do Norte, a Corte não esclareceu satisfatoriamente as razões que fundamentaram a aplicação diferenciada, em relação aos dois países, da margem de apreciação nos casos julgados.

O que se admite é que, em matéria de estado de emergência, a larga margem de apreciação conferida pela Corte aos Estados se traduz no fato de que a Corte jamais considerou uma derrogação injustificada baseada na alegação de que o estado de emergência não existiria. Observa-se também, nesse âmbito, que "a margem de apreciação revela-se mais ampla quando o estado de emergência é atual em comparação com a iminência

48 CORTE EUROPEIA DE DIREITOS HUMANOS. Brannigan e McBride v Reino Unido. Sentença de 26 de maio de 1993, parágrafo 51.

49 CORTE EUROPEIA DE DIREITOS HUMANOS. Aksoy v Turquia. Sentença de 18 de Dezembro de 1996. 
deste". ${ }^{50}$ Ainda, contraditoriamente ao fato histórico de que os maiores crimes contra a humanidade ocorreram durante estados de emergência, Ronald MacDonald, ex juiz da Corte Europeia, afirmou que "[...] é nesses períodos conturbados para a vida pública que a margem de apreciação tem sido aplicada da maneira mais ampla". ${ }^{51}$ Nesse sentido, e justificando a ideia de que o conceito estrutural da margem de apreciação deveria ser completamente abandonado, ressalta George Letsas que a fiscalização judicial em casos de derrogação conforme o Artigo 15 da Convenção Europeia de Direitos Humanos deveria ser ainda maior, porque "[...] são em situações de emergência que os governos costumam utilizar medidas excessivas contra as minorias com o objetivo de satisfazer o senso de segurança da maioria". ${ }^{52}$

$\mathrm{O}$ mesmo argumento foi manifestado em particular no julgamento do caso inglês $A v$ Secretário de Estado ${ }^{53}$ pela Câmara dos Lordes. Na opinião de Lorde Rodger, a "segurança nacional pode ser utilizada como um pretexto para medidas repressivas que são, na realidade, tomadas por outras razões", bem como nas palavras de Baronesa Hale, "[...] declarações de emergência injustificadas são uma ferramenta familiar à tirania". O fato peculiar nesse caso não foi, contudo, a aplicação do princípio da

50 No caso Grego (1969), por exemplo, a Comissão Europeia de Direitos Humanos expressou seu desacordo com o governo da Grécia que argumentava a existência de um declínio regular na ordem pública. $\mathrm{O}$ argumento era de que tal país vinha levando a nação praticamente a um estado de anarquia, o que justificava a necessidade de medidas de derrogação para evitar que o Comunismo se consolidasse no poder. A Comissão, entretanto, entendeu que não havia ameaça à vida da nação no caso. FENWICK, Helen. The AntiTerrorism, Crime and Security Act 2001: A Proportionate Response to 11 September? Modern Law Review, Londres, v.65, n.5, p. 724-762, 2002. p. 744

51 BAKIRCIOGLU, Onder. The Application of the Margin of Appreciation Doctrine in Freedom of Expression and Public Morality Cases. German Law Journal, v.8, n.7, p. 711-734, 2007. p. 714.

52 LETSAS, George. Two Concepts of the Margin of Appreciation. Oxford Journal of Legal Studies, Oxford, v.26, n.4, p.705-732, 2006. p. 730.

53 A v Secretary of State for the Home Department (2004), UKHL 56, foi um dos mais importantes casos no contexto da afirmação do papel do Judiciário em relação aos direitos protegidos pelo Human Rights Act do Reino Unido de 1998. Nesse caso, os apelantes foram notificados e detidos conforme as seções 21 e 23 do Anti-terrorism, Crime and Security Act 2001. Todos eram estrangeiros. Nenhum havia sido processado criminalmente. Os juízes ingleses deveriam então determinar "[...] se havia uma emergência pública ameaçando a vida da nação de acordo com o Artigo 15. Em caso afirmativo, se as medidas tomadas haviam excedido o que era estritamente requerido pelas exigências da situação". AMOS, Merris. Human Rights Law. Oxford and Portland: Hart Publishing, 2006. p. 91. deferência ${ }^{54}$ pela Corte de Apelação inglesa, princípio também conhecido como "margem de apreciação doméstica", mas a posterior decisão da Câmara dos Lordes, que revogou a aplicação do princípio da deferência, apesar da tradição britânica de não intromissão do Judiciário em questões de segurança nacional. A maioria dos Lordes, contrariamente ao que havia sido decidido por unanimidade pela Corte de Apelação, entendeu que a detenção infinita de suspeitos de terrorismo internacional, sem que houvesse acusação formal ou processo instaurado, era ilegal por ser tanto interferência desproporcional ao direito à liberdade perante o Artigo $5^{\circ}$ da Convenção Europeia de Direitos Humanos, quanto medida discriminatória contrária ao Artigo 14 da mesma Convenção. A conclusão enfatizada por Tomkins foi a de que "[...] mesmo no contexto de segurança nacional, o Judiciário tem a responsabilidade de assegurar que o império da lei seja respeitado". ${ }^{55}$

Conceder aos Estados uma margem de poderes discricionários facilita o arbítrio dos governantes, conforme os críticos europeus. ${ }^{56}$ Pois se um organismo internacional depende, para fazer valer sua autoridade, da “[...] cooperação dos entes que o compõe e da subordinação desses às decisões de suas instituições," segundo afirmação de Forsythe, "a doutrina da margem de apreciação formaliza as dificuldades impostas pelos Estados ao processo de uniformização dos direitos humanos internacionais". ${ }^{57} \mathrm{O}$ objetivo da doutrina da margem de apreciação, em relação à proteção internacional dos direitos humanos, é "[...] traçar a linha entre o que é adequadamente um problema para cada comunidade decidir em nível local e o que é tão fundamental que exige os mesmos requerimentos para todos os países, quaisquer que sejam as variações em tradições e cultura". ${ }^{58}$

54 O Human Rights Act, de 1998, é uma legislação que objetivou incorporar a Convenção Europeia de Direitos Humanos no território da Inglaterra e País de Gales. O princípio da deferência ou área de julgamento discricionário é considerado uma margem de apreciação doméstica no Reino Unido. Por esse princípio, certas áreas são excluídas da apreciação do Poder Judiciário, que defere a decisão a ser tomada para o Legislativo ou o Executivo. AMOS, Merris. Human Rights Law. Oxford and Portland: Hart Publishing, 2006, p. 88. 55 TOMKINS, Adam. Readings of A v Secretary of State for the Home Department. Public Law, Londres, n.2, p. 258-266, 2005, p. 263.

56 CAVANAUGH, Kathleen. Policing the margins: rights protection and the European Court of Human Rights. European Human Rights Law Review, Londres, n.4, p.422-444, 2006.

57 FORSYTHE, David. Human Rights in International Relations. 2. ed. Cambridge: Cambridge University Press, 2006, p. 23.

58 CAVANAUGH, Kathleen. Policing the margins: Rights pro- 
Contudo, se, como ensina Cançado Trindade, "O novo paradigma do Direito Internacional Público no início do século XXI não é mais estadocêntrico, situando o indivíduo na posição central", de forma que devemos considerar "[...] o despertar de uma consciência jurídica universal para a prevalência da dignidade da pessoa humana em quaisquer circunstâncias", ${ }^{59}$ afirmando assim a existência de direitos humanos universais, como sustentar a defesa dos interesses do Estado por meio da criação da doutrina da margem de apreciação pelos próprios órgãos de supervisão internacional? Como entender que sejam as organizações criadas para zelar pelo processo de universalização dos direitos humanos as responsáveis pelo desenvolvimento de mecanismos que autorizam os Estados a se desvencilharem de suas obrigações internacionais? Nesse contexto, as principais questões que são apresentadas por Delmas-Marty são: como manter as pretensões relativas ao universalismo se por meio da margem de apreciação, cada Estado insiste em manter sua especificidade? Deveria a margem de apreciação ser abandonada em nome da segurança jurídica e da proteção à ideia de universalidade na qual se fundamenta a essência dos direitos do homem, ou sua manutenção é absolutamente necessária como forma de preservação da soberania nacional? A complexidade da ideia de perseguir uma segurança jurídica em matéria de direitos humanos é sugerida pela mesma autora, ao referendar uma justificativa da própria Corte Europeia de Direitos Humanos em relação à necessidade de constante reexame das soluções jurídicas à luz das evoluções científicas e sociais que culminam com mudanças de pensamento e atitude da comunidade. A flexibilidade inerente à vida social, da qual emana o direito, impossibilita, assim, a completa realização da segurança jurídica. ${ }^{60}$

Referentemente à questão da competência entre os tribunais internacionais e os Estados, cabe elucidar: os tratados internacionais já decidiram o que é aceitável ou não em matéria de direitos humanos. A observância desses tratados deve ser garantida pelos tribunais. A doutrina da

tection and the European Court of Human Rights. European Human Rights Law Review, Londres, n.4, p. 422-444, 2006, p. 424.

59 TRINDADE, A.A Cançado. La Nueva Dimensión de las Necesidades de Protección del Ser Humano en el inicio del Siglo XXI. In: TRINDADE, A.A Cançado; RUIZ DE SANTIAGO, J. (Ed.). La Nueva Dimensión de las Necesidades de Protección del Ser Humano en el inicio del Siglo XXI. 3. ed. São José da Costa Rica: ACNUR, 2004, p.67-86.

60 DELMAS-MARTY, M. Trois défis pour um droit mondial. Paris: Éditions Du Seuil, 1998. margem de apreciação serve somente para indicar que "os Estados podem realizar qualquer ato que a Corte não considere incompatível com os direitos humanos". ${ }^{11}$ A importância dessa doutrina em Direito Internacional, repita-se, é o confronto direto entre dois princípios fundamentais, que são: o respeito à soberania estatal, e a necessidade de universalização das normas de direitos humanos. ${ }^{62}$ As críticas atuais à doutrina, contudo, entendem que a Corte tem falhado na sua aplicação de forma que o que tem acontecido na prática é uma demonstração de uso pernicioso da margem de apreciação, que "[...] evita a condução e o exame independente de provas com a consequente tendência de sucumbir à posição do governo nacional relevante". ${ }^{63}$

Nesse contexto, alerta Couto e Silva para os “[...] vícios relacionados com o exercício do poder discricionário" "64 que podem ser: transgressão dos limites do poder discricionário, abuso ou desvio do poder (ou desvio de finalidade), e não exercício ou exercício deficiente do poder discricionário. Para evitá-los, evidencia-se na história do Brasil uma constante ampliação da revisão judicial, que tem se observado modernamente em toda parte. Essa tendência de aumento de controle judicial está baseada no interesse público e nos reais limites do poder discricionário, que são a finalidade da lei, dos princípios e regras constitucionais, dos princípios fundamentais do direito e a proporcionalidade entre o ato e o fato que o determinou.

\section{Considerações finais}

Após esta breve análise da aplicação da doutrina da margem de apreciação pela Corte Interamericana de Direitos Humanos, bem como da sua formulação anterior por parte da Corte Europeia, observa-se que essa margem de discricionariedade estatal tem tido aplicação muito mais expressiva - e, portanto, problemática - no Sistema Europeu do que no Sistema Interamericano. Se na Europa as aplicações jurisprudenciais da referida dou-

61 CAVANAUGH, Kathleen. Policing the margins: Rights protection and the European Court of Human Rights. European Human Rights Law Review, Londres, n.4, p. 422-444, 2006. p. 444.

62 FELDMAN, D. Civil Liberties and Human Rights in England and Wales. 2. ed. Oxford: Oxford University Press, 2002.

63 CAVANAUGH, Kathleen. Policing the margins: Rights protection and the European Court of Human Rights. European Human Rights Law Review, Londres, n.4, p. 422-444, 2006. p. 437.

64 SILVA, Almiro Couto e. Poder Discricionário no Direito Administrativo Brasileiro. Revista de Direito Administrativo, Rio de Janeiro, v.179, n.80, p. 51-92, 1990. p. 63. 
trina por parte do Tribunal Regional para Proteção dos Direitos do Homem são frequentes e difundem a cada dia as críticas doutrinárias contrárias à prática, no continente americano a margem de apreciação foi concebida até agora em apenas uma Opinião Consultiva. Enquanto na Europa percebe-se um aumento do uso da doutrina como justificativa para a não interferência de tribunais internacionais nos assuntos relacionados aos valores morais e à cultura de cada Estado, na América a discricionariedade estatal foi ratificada no contexto da discussão acerca do direito à nacionalidade e à proibição de discriminação, porém de uma forma bastante específica.

Compartilha-se da ideia de que a margem de apreciação contribui para a aplicação não uniforme, subjetiva ou relativista do direito internacional, flexibilizando as fronteiras da legalidade. Ainda, a prática observada nos órgãos de supervisão da Europa revelou que a doutrina reforça a percepção das normas internacionais como sendo de caráter não obrigatório, ou soft law. Como consequência, trata-se de método que autoriza os Estados mais poderosos a se evadirem de suas obrigações internacionais, pois reintroduz o argumento de defesa da soberania estatal nas relações internacionais. Se a proteção à soberania por parte dos Estados já representava um obstáculo aos objetivos de universalização dos direitos humanos, a ratificação desse princípio por parte dos órgãos internacionais de supervisão não só impede a evolução do movimento de internacionalização dos direitos humanos, mas também dificulta o funcionamento dos Sistemas Regionais de proteção à pessoa.

$\mathrm{Na}$ Opinião Consultiva 4/84 da Corte Interamericana de Direitos Humanos, os próprios julgadores já demonstram uma preocupação com a disseminação do uso do poder discricionário dos Estados, quando mencionam a necessidade de aplicação restrita da margem de apreciação no tocante aos testes que devem ser aplicados para averiguar se as exigências legais para concessão da nacionalidade foram satisfeitas.

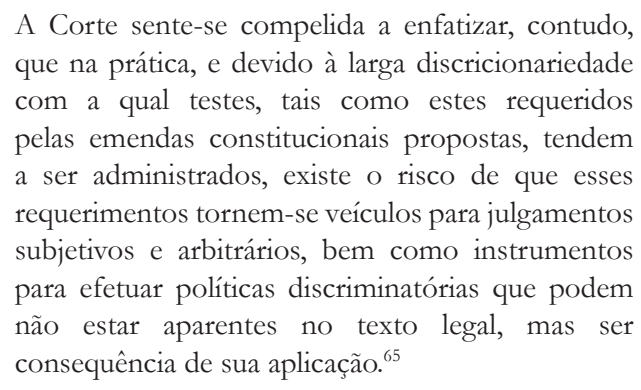

Nesse sentido, as emendas à Constituição da Costa Rica propõem testes que objetivem avaliar a existência de laços reais e efetivos nos quais se possa basear o pedido de aquisição de nova nacionalidade. Entre os requerimentos, o Artigo 15 estabelece a "[...] prova da habilidade de falar, escrever e ler o idioma oficial do país, bem como um exame que comprove conhecimentos acerca da sua história e valores". Tanto a definição de tais requerimentos como os seus modos de avaliação recaem, segundo a Corte Interamericana de Direitos Humanos, "[...] prima facie, dentro da margem de apreciação reservada ao Estado". ${ }^{66}$

Em contrapartida, a adoção da margem de apreciação como justificativa de deferência para as autoridades locais no julgamento de violações aos direitos humanos durante estado de emergência, bastante comum na Europa, ainda (e felizmente) não encontrou guarida na prática Interamericana. Entende-se, por isso, que se na Europa o uso muitas vezes indiscriminado da margem de apreciação forneceu subsídios para fomentar críticas da doutrina especializada com relação aos perigos que tal prática representa para a efetivação dos direitos humanos, na América foi justamente a restrição do uso desse mecanismo por parte do Tribunal Interamericano que impediu a difusão da preocupação com a sua aplicação. Conclui-se, portanto, que a cautela demonstrada pela Corte Interamericana de Direitos Humanos ao invocar a margem de apreciação na fundamentação da Opinião Consultiva 4/84 explica o reduzido desenvolvimento dessa doutrina na jurisprudência do Sistema Interamericano.

\section{ReferênCiAs}

AMOS, Merris. Human Rights Law. Oxford and Portland: Hart Publishing, 2006.

BAKIRCIOGLU, Onder. The Application of the Margin of Appreciation Doctrine in Freedom of Expression and Public Morality Cases. German Law Journal, v.8, n. 7, p.711-734, 2007.

MANOS. Opinião Consultiva sobre propostas de emendas aos dispositivos constitucionais que regem a naturalização na Costa Rica, Opinião $n^{\circ} 4 / 84$. Parecer de 19 de janeiro de 1984. p. 17.

66 CORTE INTERAMERICANA DE DIREITOS HUMANOS. Opinião Consultiva sobre propostas de emendas aos dispositivos constitucionais que regem a naturalização na Costa Rica, Opinião n ${ }^{\circ}$ 4/84. Parecer de 19 de janeiro de 1984. p. 17. 
BOYLE, Kevin. Human Rights, Religion and Democracy: The Refah Party Case. Essex Human Rights Review, Essex, v. 1, n. 1, p. 1-16, jul. 2004. Disponível em: $<$ http://projects.essex.ac.uk/EHRR/archive/>. Acesso em: 24 out. 2006.

CÂMARA DOS LORDES DO REINO UNIDO 56. $A$ and Others $v$ Secretary of State for the Home Department. 2004. Sentença de 16 de dezembro.

CAVANAUGH, Kathleen. Policing the margins: rights protection and the European Court of Human Rights. European Human Rights Law Review, Londres, n. 4, p. 422444, 2006.

CHARLESWORTH, H., CHINKIN, C. The Boundaries of International Law: a feminist analysis. Manchester: Manchester University Press, 2000.

CONSELHO DA EUROPA. Convenção para a Proteção dos Direitos Humanos e Liberdades Fundamentais, de 4 de novembro de 1950.

CORTE EUROPEIA DE DIREITOS HUMANOS. Caso Linguístico Belga. Sentença de 23 de julho, 1968.

CORTE EUROPEIA DE DIREITOS HUMANOS. Aksoy v Turquia. Sentença de 18 de dezembro, 1996.

CORTE EUROPEIA DE DIREITOS HUMANOS. $B$ $v$ França. Sentença de 24 de janeiro, 1992.

CORTE EUROPEIA DE DIREITOS HUMANOS. Brannigan e McBride v Reino Unido. Sentença de 26 de maio, 1993.

CORTE EUROPEIA DE DIREITOS HUMANOS. Brogan v Reino Unido. Sentença de 29 de novembro, 1988.

CORTE EUROPEIA DE DIREITOS HUMANOS. Convenção Americana sobre Direitos Humanos, 22 de novembro de 1969.

CORTE EUROPEIA DE DIREITOS HUMANOS. Cossey v Reino Unido. Sentença de 27 de setembro, 1990.

CORTE EUROPEIA DE DIREITOS HUMANOS. Frette v França. Sentença de 26 de fevereiro, 2002.

CORTE EUROPEIA DE DIREITOS HUMANOS. Goodwin v Reino Unido. Sentença de 11 de julho, 2002.

CORTE EUROPEIA DE DIREITOS HUMANOS. Handyside $v$ Reino Unido. Sentença de 7 de dezembro, 1976.

CORTE EUROPEIA DE DIREITOS HUMANOS. Irlanda v Reino Unido. Sentença de 18 de janeiro, 1978.
CORTE EUROPEIA DE DIREITOS HUMANOS. Lawless v Irlanda. Sentença de 14 de novembro, 1990.

CORTE EUROPEIA DE DIREITOS HUMANOS. Otto-Preminger Institute v Áustria. Sentença de 20 de setembro, 1994.

CORTE EUROPEIA DE DIREITOS HUMANOS. Partido Comunista Unido da Turquia e outros v Turquia. Sentença de 30 de janeiro, 1998.

CORTE EUROPEIA DE DIREITOS HUMANOS. Partido Refah (O Partido do Bem-Estar e outros v Turquia). Sentença de 13 de fevereiro, 2003.

CORTE EUROPEIA DE DIREITOS HUMANOS. Rees v Reino Unido. Sentença de 17 de outubro, 1986.

CORTE EUROPEIA DE DIREITOS HUMANOS. Sheffield e Horsham v Reino Unido. Sentença de 30 de julho, 1998.

CORTE EUROPEIA DE DIREITOS HUMANOS. Wingrove v Reino Unido. Sentença de 25 de novembro, 1996.

CORTE INTERAMERICANA DE DIREITOS HUMANOS. Opinião Consultiva sobre propostas de emendas aos dispositivos constitucionais que regem a naturalização na Costa Rica, Opinião nº 4/84. Parecer de 19 de janeiro de 1984.

COSTA RICA. Constituição Política da República, de 8 de novembro de 1949.

DEL MORAL, Ignacio de la Rasilla. The Increasingly Marginal Appreciation of the Margin of Appreciation Doctrine. German Law Journal, v.7, n.6, p. 611-624, 2006.

DELMAS-MARTY, M. Trois défis pour um droit mondial. Paris: Éditions Du Seuil, 1998.

FELDMAN, David. Civil Liberties and Human Rights in England and Wales. 2. ed. Oxford: Oxford University Press, 2002.

FENWICK, Helen. The Anti-Terrorism, Crime and Security Act 2001: A Proportionate Response to 11 September? Modern Law Review, Londres, v.65, n.5, p. 724762, 2002.

KLUG, Francesca. Values for a Godless Age: The story of the United Kingdom's Bill of Rights. Londres: Penguin Books, 2000.

LAFER, Celso. A Reconstrução dos Direitos Humanos: Um diálogo com o pensamento de Hannah Arendt. São Paulo: Companhia das Letras, 1998.

LETSAS, George. Two Concepts of the Margin of Ap- 
preciation. Oxford Journal of Legal Studies, Oxford, v.26, n.4, p.705-732, 2006.

MCGOLDRICK, Dominic. Multiculturalism and its Discontents. Human Rights Law Review, Oxford, v. 5, n. 1, p. 27-56, 2005.

NAÇÕES UNIDAS. Declaração Universal dos Direitos Humanos, 12 de dezembro de 1948.

ORGANIZAÇÃO DOS ESTADOS AMERICANOS. Declaração Americana dos Direitos e Deveres do Homem, abril de 1948.

ORSYTHE, David. Human Rights in International Relations. 2.ed. Cambridge: Cambridge University Press, 2006.

SAMUELS, Harriet. Methodological Approaches by the Courts to the Human Rights Act 1998; Examples of the Convention's Application. Some Introductory Principles. Faculdade de Direito da Universidade de Westminster, (aula). Londres, 7 de novembro de 2006.
SILVA, Almiro Couto e. Poder Discricionário no Direito Administrativo Brasileiro. Revista de Direito Administrativo, Rio de Janeiro, v.179, n.80, p.51-92, jan./jun. 1990.

SHANY, Yuval. Toward a General Margin of Appreciation Doctrine in International Law? European Journal of International Law, Florença, v.16, n.5, p. 907-940, 2005.

TANCA, Antonio. Human Rights, Terrorism and Policy Custody: The Brogan Case. European Journal of International Law, Florença, v.1, n.1, p.269-277, 1990.

TOMKINS, Adam. Readings of A v Secretary of State for the Home Department. Public Law, Londres, n.2, p.258-266, 2005.

TRINDADE, A.A Cançado. La Nueva Dimensión de las Necesidades de Protección del Ser Humano en el inicio del Siglo XXI. In TRINDADE, A.A Cançado e RUIZ DE SANTIAGO, J. (Ed.). La Nueva Dimensión de las Necesidades de Protección del Ser Humano en el inicio del Siglo XXI. 3.ed. São José da Costa Rica: ACNUR, 2004. 
Para publicar na Revista de Direito Internacional, acesse o endereço eletrônico www.rdi.uniceub.br ou www.brazilianjournal.org.

Observe as normas de publicação, para facilitar e agilizar o trabalho de edição. 